\title{
PENGEMBANGAN MODUL FISIKA BERBASIS KONTEKSTUAL UNTUK MENINGKATKAN KEMAMPUAN BERPIKIR KRITIS DAN KREATIVITAS SISWA PADA MATERI KALOR DAN PERPINDAHANNYA
}

\author{
Marlinda Mega Dwi Prastuti ${ }^{1}$, Sukarmin ${ }^{2}$, Nonoh Siti Aminah ${ }^{3}$ \\ ${ }^{1}$ Program Studi Magister Pendidikan Sains FKIP Universitas Sebelas Maret \\ Surakarta, 57126, Indonesia \\ marlinda.mdp@student.uns.ac.id \\ ${ }^{2}$ Program Studi Magister Pendidikan Sains FKIP Universitas Sebelas Maret \\ Surakarta, 57126, Indonesia \\ sukarmin67@staff.uns.ac.id \\ ${ }^{3}$ Program Studi Magister Pendidikan Sains FKIP Universitas Sebelas Maret \\ Surakarta, 57126, Indonesia \\ nonoh.nst@staff.uns.ac.id
}

\begin{abstract}
Abstrak
Media pembelajaran yang sesuai dengan pendekatan kontekstual masih sangat terbatas. Tujuan penelitian ini adalah untuk mengetahui (1) karakteristik modul Fisika berbasis kontekstual pada materi kalor dan perpindahannya; (2) kelayakan terhadap modul Fisika berbasis kontekstual siswa pada materi kalor dan perpindahannya; (3) peningkatan tingkat berpikir kritis dan kreativitas siswa setelah menggunakan modul Fisika berbasis kontekstual pada materi kalor dan perpindahannya. Metode penelitian dan pengembangan yang digunakan Research and Development $(\mathrm{R} \& \mathrm{D})$. Model penelitian menggunakan model penelitian 4D dengan langkah: (1) tahap pendefinisian (define), (2) tahap perancangan (design), (3) tahap pengembangan (develop), (4) tahap penyebaran (dessiminate). Pengembangan modul meliputi proses validasi kelayakan modul, revisi modul, dan aplikasi modul pembelajaran berbasis kontekstual di kelas X1 SMAN 1 Sumberlawang. Analisis data yang digunakan selama penelitian adalah analisis deskriptif berdasarkan skor kriteria dan analisis peningkatan kreativitas belajar siswa melalui nilai gain. Hasil Penelitian disimpulkan bahwa: (1) karakteristik khusus pengembangan modul ini berdasarkan sintakssintaks pembelajaran kontekstual yang dituangkan pada rubrik dalam modul; (2) modul ini layak untuk digunakan sebagai bahan ajar. Hasil perhitungan cut off score menunjukkan modul masuk dalam kategori layak dengan nilai 3,62 dalam skala 4 dengan kategori sangat baik; (3) pembelajaran dengan menggunakan modul ini dapat meningkatkan kreativitas belajar siswa dan kemampuan berpikir kritis siswa, dilihat dari skor rata-rata peningkatan kreativitas dan kemampuan berpikir kritis sebelum dan sesudah menggunakan modul dengan persamaan gain ternormalisasi diperoleh nilai 0,56 untuk kreativitas belajar siswa dan 0,50 untuk kemampuan berpikir kritis dengan kriteria gain ternormalisasi kategori sedang.
\end{abstract}

Kata Kunci: Modul Fisika berbasis kontekstual, kreativitas belajar, kemampuan berpikir kritis.

\section{Pendahuluan}

Salah satu tujuan dari suatu proses pembelajaran adalah terbentuknya peserta didik yang berkualitas baik. Peserta didik mampu menguasai segala keterampilan dan kecakapan dalam mencerna komunikasi dengan baik. Hal ini dikuatkan dengan Sugiyanto (2013), menjelaskan bahwa proses pembelajaran adalah suatu proses komunikasi untuk menyampaikan informasi pada peserta didik. Informasi tersebut dapat berupa pengetahuan yang sistematis, untuk dapat dikuasai peserta didik dengan baik. 
Kenyataan di lapangan sangat jauh berbeda, kualitas pendidikan di Indonesia saat ini cukup memprihatinkan. Berdasarkan hasil PISA (the Program for Internasional Student Assesment) pada tahun 2012. Indonesia berada pada peringkat ke-64 dari 65 negara dengan perolehan skor sains 382 yang berada jauh dari rata-rata yaitu 501(Schleicher, 2014). Pada literasi membaca Indonesia berada pada peringkat ke 48 dari 56 negara (OECD, 2007).

Salah satu bagian dari ilmu sains adalah Fisika. Fisika merupakan ilmu dasar perkembangan teknologi di dunia, begitupun di Indonesia. Hal ini dinyatakan oleh Maharta (2010), bahwa Fisika merupakan ilmu fundamental dalam perkembangan pengetahuan dan teknologi. Dengan adanya ilmu Fisika, banyak benda dan alat teknologi tinggi tercipta, sehingga dalam negara yang berkembang seperti Indonesia sangat diperlukan pemahaman dan penerapan yang mendalam kepada anak bangsanya.

Pembelajaran Fisika dianggap susah dan rumit bagi siswa karena dalam penyajiannya sangat komplek (Suparno, 2009). Salah satu contohnya adalah siswa harus dapat mengubah dari bentuk penyajian grafik ke penyajian matematis, eksperimen, rumusan dan kalkulasi, grafik, dan penjelasan konseptual pada waktu yang sama (Ornek, 2008).

Kualitas pembelajaran Fisika pada peserta didik dipengaruhi oleh banyak faktor. Faktor-faktor yang mempengaruhi suatu pembelajaran dapat berasal dari luar dan dalam pribadi peserta didik. Faktorfaktor itu meliputi kualitas guru dalam pembelajaran, fasilitas, media pembelajaran, iklim pembelajaran, dan pribadi siswa yang merupakan faktor yang paling utama. Jalannya pembelajaran sangat dipengaruhi oleh guru sebagai fasilitator, salah satu hal yang dilakukan fasilitator adalah menyediakan media pembelajaran bagi peserta didik dengan baik. Adanya sumber dan media yang mampu meningkatkan kualitas pembelajaran (Sugiyanto, 2013).
Materi pembelajaran Fisika pada materi kalor dan perpindahannya di kelas $\mathrm{X}$ SMA merupakan materi pelajaran Fisika yang cukup komplek dan perlu pemahaman yang mendalam. Hal ini dikuatkan dengan hasil angket kebutuhan yang telah dilakukan terhadap siswa, $86 \%$ siswa menggangap materi Kalor dan Perpindahannya merupakan materi yang sulit. Mayoritas cakupan materi ini berupa pemahaman konsep, hitungan dengan banyak persamaan dan penerapan dalam kehidupan sehari-hari sehingga siswa perlu memahami dan menghafal. Hal ini otomatis membuat penyajian materi Fisika khususnya pada materi kalor dan perpindahannya secara baik. Penyajian pembelajaran Fisika sangatlah penting karena pelajaran Fisika membutuhkan visualisasi karena pelajarannya yang sudah bersifat abstrak. Berdasarkan penelitian yang dilakukan oleh Goldin (2012), Fisika dipahami sebagai pelajaran yang sulit dalam penyajiannya karena Fisika menuntut penguasaan siswa dalam representasirepresentasi yang berbeda yaitu dalam grafik, konseptual, rumus, percobaan dan gambar. Hal ini akan membuat anak akan lebih cepat bosan jika mempelajari materi kalor dan perpindahannya dengan media yang biasa seperti buku pada umumnya.

Buku pelajaran di sekolah sangat jarang yang menampilkan penyajian materi yang aplikatif, meskipun sudah ada variasi perbaikan buku pelajaran tetapi belum memberikan pengaruh yang cukup terhadap peningkatan minat baca siswa. Minat membaca yang rendah menyebabkan keaktifan dan hasil belajar menjadi rendah (Wahyuningsih, 2011). Hal ini juga terjadi pada media ajar pembelajaran Fisika. Banyak media ajar Fisika dikemas dengan buku yang kaku atau bacaan yang menjemukan dan menimbulkan rasa bosan ketika dipelajari. Selain tidak dapat menumbuhkan rasa cinta membaca, hal ini dapat menimbulkan rasa tidak suka terhadap pembelajaran Fisika. Rasa tidak suka Fisika ini akan berpengaruh pada keaktifan siswa dalam belajar dan berakibat 
kurangnya pemahaman pada mata pelajaran sains khususnya Fisika.

Pemahaman terhadap konsep Fisika yang diajarkan mempengaruhi tingkat berpikir kritis siswa. Peraturan Pemerintah no. 19 tahun 2005 pasal 6 ayat (1) butir (c) menyatakan bahwa kelompok mata pelajaran ilmu pengetahuan dan teknologi bertujuan agar peserta didik memperoleh kompetensi dasar ilmu pengetahuan dan teknologi serta membudayakan berpikir ilmiah secara kritis, kreatif, dan mandiri. Kemampuan berpikir kritis dapat diajarkan melalui sebuah pendidikan agar mampu menilai dengan akurat, dan berargumentasi dengan baik. Hal ini akan terlihat pada saat kegiatan pembelajaran berlangsung, diperlukan kegiatan pembelajaran yang aktif dan kondusif. Hal ini bertujuan agar pengembangan kemampuan siswa dapat berjalan dengan baik. Sejalan dengan tujuan tersebut, pada pembelajaran Fisika yang merupakan pelajaran eksak dituntut kemampuan berpikir kritis. Mundilarto (2013) menjelaskan bahwa kemampuan berpikir kreatif dan kritis dituntut dalam mempelajari materi eksak seperti Fisika. Sehingga pembelajaran Fisika dapat menjadi pendorong yang kuat tumbuhnya sikap rasa ingin tahu, keterbukaan terhadap ide-ide baru, dan dapat membantu siswa memahami pentingnya berpikir kritis kreatif dalam memecahkan masalah (Suparno, 2009).

Upaya pengembangan kemampuan siswa dalam pelajaran Fisika yang baik diimbangi dengan karakter siswa yang baik. Karakter siswa dalam ranah afektif yang sangat penting adalah kreativitas. Pengembangan dan penerapan nilai-nilai karakter sebagai dirinya dalam kehidupan pribadi, masyarakat dan warga negara yang religius, nasionalis, produktif, dan kreatif (Noperi, 2014). Pada kenyataannya karakter kreativitas masih sangat kurang dikembangkan dalam pembelajaran secara formal. Proses pendidikan di Indonesia saat ini terlalu mementingkan aspek kognitif dan mengabaikan kreativitas. Proses pengajaran di sekolah lebih mementingkan target pencapaian kurikulum dibandingkan dengan pemahaman siswa yang baik (Asmani, 2011).

Pentingnya kreativitas merupakan tuntutan kurikulum agar siswa mampu menghadapi persoalan baik di kelas maupun di luar kelas yang semakin kompleks dan tidak bergantung pada orang lain. Hal ini dikuatkan dengan Suryani dan Fatkhullah (2012) yang menjelaskan bahwa sebagian besar siswa pada umumnya memandang pembelajaran yang menekankan kreativitas lebih menantang dan memotivasi dalam belajar.

Berdasarkan hasil angket kebutuhan terhadap siswa dan guru di SMAN 1 Sumberlawang, 83\% siswa dan $100 \%$ guru menyatakan adanya keterbatasan pada buku pegangan yang digunakan dalam pembelajaran. 95\% siswa dan $100 \%$ guru memilih media ajar yang lebih baik dibandingkan buku yang ada disekolah, media ajar diharapkan lebih berkaitan dengan kehidupan sehari-hari atau berbasis kontekstual. Salah satu media ajar yang menunjang kegiatan belajar dan dikehendaki pada saat ini salah satunya adalah modul. Pada SMAN 1 Sumberlawang bahan ajar yang berbentuk modul bagi siswa belum pernah diadakan, bahkan buku pelajaran yang konvensional di sekolah sangatlah terbatas.

Hasil wawancara lisan dengan guru Fisika SMA Negeri 1 Sumberlawang, diperoleh gambaran dan keterangan bahwa adanya kelemahan siswa dalam berpikir kritis. Siswa kurang bisa mengungkapkan aplikasi Kalor dan perpindahannya, siswa kurang dapat menunjukkan kemampuan berpikir secara kritis. Selain itu, guru juga menjelaskan kurangnya tergambar kreativitas yang kuat dan baik pada diri siswa. Siswa cenderung masih tergantung pada guru, ketika siswa diajak menemukan suatu konsep secara mandiri.

Pembelajaran yang inovatif hendaknya dikaitkan dengan kehidupan sehari-hari. Siswa akan lebih mudah ingat jika yang diajarkan oleh guru diterapkan 
langsung oleh siswa. Siswa dapat menghubungkan langsung apa yang mereka pelajari dengan kehidupan sehari-hari dengan menggunakan pembelajaran kontekstual. Muslich dalam Syahbana (2004) menjelaskan bahwa pendekatan kontekstual atau Contextual Teaching and Learning (CTL) adalah pendekatan pembelajaran yang mengkaitkan antara materi yang dipelajari dengan konteks kehidupan sehari-hari siswa. Pembelajaran kontekstual melibatkan keaktifan peserta didik dalam menggunakan pengetahuan yang telah dimiliki dalam proses pembelajaran.

Depdiknas (2007) menyatakan ada tujuh komponen utama pembelajaran yang mendasari penerapan pembelajaran kontekstual di kelas. Ketujuh komponen itu adalah konstruktivisme (constructivism), bertanya (questioning), inkuiri (inquiry), masyarakat belajar (learning community), pemodelan (modelling), refleksi (reflection) dan penilaian autentik (authentic assessment). Menurut Johnson (2010), ketujuh komponen utama pembelajaran kontekstual ini, sangatlah sinkron dengan upaya memunculkan kemampuan berpikir kritis siswa terutama pada komponen bertanya, menemukan, dan refleksi. Melalui ketiga komponen ini diharapkan siswa mampu memanfaatkan model (pemodelan) yang ada, kemudian mengkonstruksi pemahaman sendiri (konstruktivis) terhadap apa yang dipelajarinya (Syahbana, 2012).

Pembelajaran kontekstual juga diharapkan akan meningkatkan karakter kreativitas siswa. Pembelajaran kontekstual menurut Johnson memiliki delapan komponen utama, yaitu: melakukan hubungan yang bermakna, melakukan pekerjaan atau kegiatan yang signifikan, belajar yang diatur sendiri, bekerjasama, berpikir kritis dan kreatif, memelihara pribadi siswa, mencapai standar tinggi dan penilaian yang autentik. Beberapa komponen kontekstual menunjukkan aspek kemampuan kreativitas. Diharapkan dengan pendekatan kontekstual, kemampuan kreativitas siswa akan meningkat (Lestari, 2014).

Modul Fisika yang berbasis kontekstual merupakan salah satu solusi media yang dapat menumbuhkan penekanan pada tingkat berpikir kritis dan kreativitas siswa. Modul Fisika yang berbasis kontekstual sangat diperlukan untuk menunjang kegiatan pembelajaran di SMAN 1 Sumberlawang. Dengan perpaduan tersebut, diharapkan siswa akan lebih tertarik dalam mempelajari pembelajaran Fisika pada materi Kalor dan perpindahannya pada kelas X SMA.

Berdasarkan penjelasan latar belakang masalah diatas penelitian ini bertujuan untuk mengetahui (1) karakteristik modul Fisika berbasis kontekstual untuk meningkatkan tingkat berpikir kritis dan kreativitas siswa pada materi kalor dan perpindahannya; (2) kelayakan terhadap modul Fisika berbasis kontekstual untuk meningkatkan tingkat berpikir kritis dan kreativitas siswa pada materi kalor dan perpindahannya; (3) mengetahui peningkatan tingkat berpikir kritis dan kreativitas siswa setelah menggunakan modul Fisika berbasis kontekstual untuk meningkatkan tingkat berpikir kritis dan kreativitas siswa pada materi kalor dan perpindahannya.

\section{Metode Penelitian}

Metode penelitian yang digunakan adalah penelitian dan pengembangan (research and development). Penelitian pengembangan adalah metode penelitian yang digunakan untuk menghasilkan produk tertentu dan menguji keefektifan produk tersebut (Sugiyono, 2012). Model yang digunakan sebagai dasar untuk mengembangkan modul Fisika berbasis kontekstual ini merupakan hasil adaptasi model 4-D (four-D model) yang dikemukakan oleh Thiagarajan (1974:5). Langkah penelitian ini meliputi proses define, design, develop, dan disseminate.

Penelitian dilaksanakan pada siswa kelas X 1 SMAN 1 Sumberlawang tahun 
ajaran 2015/2016 dengan materi yang digunakan adalah kalor dan perpindahannya. Desain penelitian yang digunakan adalah one group pretest and posttest, sehingga penelitian hanya melibatkan sekelompok subjek yang diberi pre-test sebelum dikenai perlakuan, dan post-test setelah dikenai perlakuan untuk diketahui hasil akibat perlakuan tersebut.

Instrumen pengumpulan data yang digunakan dalam penelitian ini adalah: (1) instrumen observasi yang meliputi lembar observasi kreativitas belajar siswa, lembar observasi hasil belajar dari aspek sikap, dan lembar observasi hasil belajar dari aspek keterampilan. Lembar observasi dan angket kreativitas diadaptasi dari teori Munandar dalam Harsono (2009) yang diambil dari lima aspek afektif yaitu rasa ingin tahu, imajinatif, tertantang kemajemukan, berani mengambil resiko, dan sifat menghargai; (2) angket yang meliputi angket kreativitas, angket penilaian produk, angket kebutuhan siswa, dan angket analisis kebutuhan guru; (3) lembar validasi materi, media dan bahasa, praktisi dan teman sejawat; (4) tes yang meliputi tes kemampuan berpikir kritis dan lembar penilaian aspek pengetahuan. Instrumen-instrumen yang digunakan sudah melalui validasi oleh pembimbing.

Data yang diperoleh pada penelitian pengembangan modul berbasis kontekstual pada materi kalor dan perpindahannya untuk siswa SMA/MA kelas X adalah data analisis kebutuhan siswa, data analisis kebutuhan guru, data validasi modul oleh validator ahli (materi, bahasa dan kegrafikan), guru fisika dan teman sejawat, data nilai sikap, pengetahuan dan keterampilan, data nilai peningkatan kreativitas belajar siswa, penilaian peningkatan kemampuan berpikir kritis dan data penilaian produk oleh siswa, guru fisika, dan teman sejawat. Data yang diperoleh dari analisis kebutuhan siswa dan analisis kebutuhan guru ditabulasi dan dikonversi menjadi bentuk persentase. Hasil validasi modul, nilai sikap, nilai keterampilan dan hasil penilaian produk dianalisis dan dikonversi menjadi skala 4 kemudian dilakukan analisis deskriptif terhadap hasilnya. Hasil penilaian pengetahuan dianalisis dengan membuat rata-rata nilai kemudian dibandingkan dengan kriteria ketuntasan minimal mata pelajaran fisika, sedangkan hasil pretest dan posttest dari tes kemampuan berpikir kritis dan juga hasil angket sebelum dan sesudah kreativitas belajar siswa dianalisis dan ditentukan peningkatannya dengan n-gain ternormalisasi (Meltzer, 2001). Kreativitas belajar siswa dikatakan meningkat ketika hasil perhitungan gain minimal memiliki kategori sedang (Syaifudin, 2011).

\section{Hasil Penelitian dan Pembahasan}

Model yang digunakan sebagai dasar untuk mengembangkan modul fisika berbasis kontekstual ini merupakan hasil adapatasi model 4-D (four-D model) yang dikemukakan oleh Thiagarajan (1974: 5) yang meliputi proses define, design, develop, dan disseminate yang menunjukkan hasil sebagai berikut :

\section{Tahap Define}

Tahap ini merupakan tahapan untuk mengidentifikasi masalah-masalah yang ada dalam proses pembelajaran dan menjadi dasar untuk merancang produk berupa modul yang dibuat. Pada tahapan ini dilakukan analisis kebutuhan siswa, analisis kebutuhan guru dan analisis materi pembelajaran. Analisis kebutuhan siswa dilakukan pada 26 siswa kelas $\mathrm{X}$ dan analisis kebutuhan guru dilakukan pada 2 orang guru Fisika di SMAN 1 Sumberlawang. Data yang dihasilkan 100\% guru dan $83 \%$ siswa mengungkapkan adanya keterbatasan bahan ajar dari penerbit. Pembelajaran dilakukan kurang kontekstual, hanya $17 \%$ siswa berpendapat guru sudah menyampaikan pelajaran secara kontekstual. Berdasarkan hasil analisis kebutuhan guru dan siswa, didapatkan kreativitas belajar siswa yang rendah. $34 \%$ siswa dan $40 \%$ guru menilai tingkat 
kreativitas yang dimiliki siswa secara keseluruhan.

Hasil analisis materi berdasarkan hasil analisis kebutuhan siswa yang menyatakan $86 \%$ siswa beranggapan materi kalor dan perpindahannya cukup sulit. Hal ini diperkuat dengan hasil persentase penguasaan materi Kalor dan Perpindahannya di SMAN 1 Sumberlawang pada tahun pelajaran 2013/2014 berdasarkan BSNP SMA/MA. Tahun Pelajaran 2013/2014. Untuk materi Kalor dan perpindahannya pada tingkat sekolah $55,90 \%$, tingkat kabupaten sebesar $60,14 \%$, tingkat propinsi $72,20 \%$ dan tingkat nasional $68,76 \%$. Daya serap siswa SMAN 1 Sumberlawang masih tergolong cukup atau dapat dikatakan kurang baik. Atas dasar itu layak peneliti menggunakan materi kalor dan perpindahannya untuk dikembangkan. Hal ini bertujuan sesuai dengan penelitian Tze Kiong (2011) bahwa penggunaan modul dapat menjadi alternatif dalam pemecahan masalah belajar siswa.

\section{Tahap Design}

Pada tahapan ini dilakukan perancangan draft modul yang akan dikembangkan. Bagian-bagian modul yang akan dikembangkan meliputi identitas modul, kata pengantar, daftar isi, aspek CTL, petunjuk penggunaan modul, bagianbagian modul, peta konsep, pendahuluan modul, kegiatan belajar, uraian materi, contoh soal, rangkuman materi, info tokoh, info berita, evalusi, umpan balik, kunci jawaban, glosarium, dam daftar pustaka Modul ini akan dikembangkan berdasarkan sintaks kontekstual atau CTL.

Dalam modul ini terdapat dua kegiatan belajar, KB.1 berisikan materi Kalor dan KB.2 berisikan materi mengenai Perpindahan Kalor. Pada setiap materi akan dibagi menjadi beberapa submateri. Materi kalor terdiri dari konsep kalor, asas Black, dan perubahan wujud zat. Materi Perpindahan Kalor dibagi menjadi beberapa submateri yaitu Konduksi, Konveksi, dan Radiasi.
Sintaks Konstruktivisme (Contructivism) pada desain modul berbasis kontekstual ini dikemas dalam rubrik "Mari Mengamati “. Sintaks kedua bertanya (Questioning) yaitu dikemas pada rubrik "Mari Bertanya". Sintaks ketiga adalah Menemukan (Inquiry) yang dimuat pada rubrik "Mari Mencoba". Sintaks yang keempat adalah Masyarakat belajar (Learning comunity) dimuat dalam rubrik "Mari Berdiskusi". Sintaks yang kelima yaitu Pemodelan (Modelling) dikemas dalam rubrik "Mari Tunjukkan". Sintaks keenam yaitu Refleksi(Reflection) dimuat dalam rubrik "Mari Ingat Kembali". Sintaks yang ketujuh adalah Penilaian sebenarnya (Authentic assesment) yang dimuat pada "Mari Kita Uji". Modul yang dikembangkan merupakan media pembelajaran dengan sintaks-sinteks pembelajaran kontekstual. Sumber belajar yang dirancang atau dikembangkan sesuai komponen instruktisional tertentu akan mempermudah keterlaksanaan pembelajaran yang lebih terarah (Rianawaty, 2011). Media pembelajaran merupakan alat komunikasi yang dimanfaatkan untuk keperluan pembelajaran (Anitah, 2008). Modul yang sudah jadi kemudian divalidasi dan direvisi sesuai dengan tahap selanjutnya yaitu tahap pengembangan (develop) dalam proses penelitian ini.

\section{Tahap Develop}

Tahapan Develop ini diawali dengan validasi draft I modul fisika berbasis kontekstual yang dilakukan oleh validator ahli, guru fisika dan teman sejawat yang selanjutnya direvisi dan ujicobakan ke kelompok kecil dan kelompok besar.

\section{Hasil Validasi Modul}

Validasi dilakukan oleh tiga validator ahli, dua guru fisika dan dua teman sejawat. Validasi dilakukan menggunakan lembar validasi yang mengadaptasi lembar validasi buku teks pelajaran dari BSNP sesuai kebutuhan 
peneliti. Validasi modul menitikberatkan pada komponen kelayakan isi dan penyajian, bahasa, dan kelayakan kegrafisan. Tiga validator ahli memvalidasi modul yang telah dibuat dengan menilai aspek penyajian materi, aspek kebahasaan, dan aspek media yang berupa tampilan dan gambar. Dua guru fisika dan dua teman sejawat juga menilai aspek materi, bahasa dan media. Diagram batang hasil validasi modul pembelajaran berbasis kontekstual yang dikembangkan peneliti diperlihatkan dalam Gambar 1.

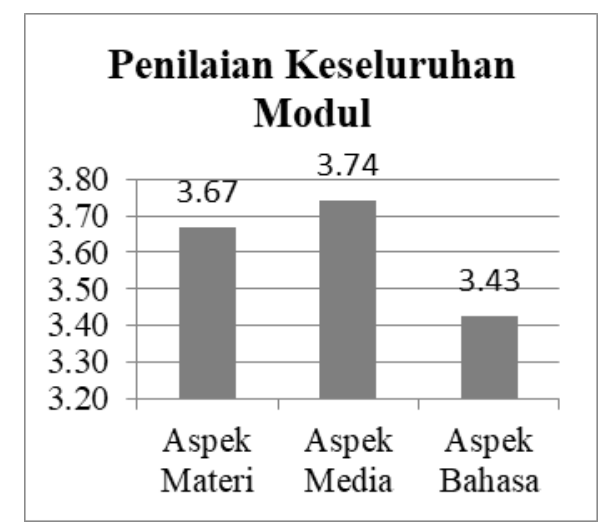

Gambar 1. Hasil validasi Modul

Hasil validasi yang ditunjukkan Gambar 1 memperlihatkan bahwa modul pembelajaran berbasis kontekstual yang dikembangkan oleh peneliti mendapatkan nilai secara keseluruhan mendapatkan nilai rata-rata 3,61 atau dalam kategori 'sangat baik'. Nilai ini berarti bahwa modul yang dikembangkan sangat baik dari segi isi dan penyajian, kebahasaan, penyajian dan kegrafikan sehingga sangat layak digunakan dalam pembelajaran. Hal ini juga sesuai dengan hasil perhitungan dengan metode metode cut off (Winnie, 2009). Nilai yang dihasilkan dari analisis cut off adalah 3,55 dan nilai rata-rata penilaian modul adalah 3,62 dalam skala 4. Hal ini menunjukkan bahwa nila rata-rata penilaian lebih besar dibandingkan nilai analisis cut off, sehingga dapat disimpulkan bahwa modul tersebut layak untuk digunakan dalam pembelajaran.

\section{Revisi I}

Setelah validasi dilakukan, draft I kemudian direvisi berdasarkan saran/ masukan dari validator seperti ditampilkan dalam Tabel 1.

Tabel 1. Hasil Revisi Modul dari Validator

\begin{tabular}{|c|c|}
\hline Sebelum & Setelah \\
\hline Revisi & Revisi \\
\hline Penulisan & Penulisan \\
\hline $\begin{array}{l}\text { persamaan } \quad \text { harus } \\
\text { konsisten secara vektor } \\
\text { maupun skalar. }\end{array}$ & $\begin{array}{lr}\text { persamaan } & \text { baik } \\
\text { simbol vektor maupun } \\
\text { skalar } & \text { sudah } \\
\text { diperbaiki. } & \\
\end{array}$ \\
\hline \begin{tabular}{lr}
\multicolumn{3}{c}{ Konsep } \\
materi & percobaan, \\
misalnya & pada \\
percobaan & mari \\
mencoba 4. & Apa \\
perbedaannya & dengan \\
materi SMP. Harap \\
diperdalam materinya.
\end{tabular} & $\begin{array}{l}\text { Pada mari } \\
\text { mencoba } 4 \text { sudah } \\
\text { ditambahi beberapa } \\
\text { variabel eksperimen. }\end{array}$ \\
\hline Beberapa & Pertanyaan \\
\hline $\begin{array}{lr}\text { pertanyaan } & \text { yang } \\
\text { ambigu } & \text { mohon } \\
\text { diperbaiki kembali. }\end{array}$ & $\begin{array}{l}\text { yang ambigu atau } \\
\text { kurang jelas sudah } \\
\text { diperbaiki. }\end{array}$ \\
\hline \begin{tabular}{lr}
\multicolumn{2}{c}{ Terjadi } \\
beberapa pengulangan \\
keterangan persamaan \\
yang tidak perlu \\
dijelaskan & kembali \\
seperti pada & halaman \\
32. & \\
\end{tabular} & $\begin{array}{l}\text { Keterangan } \\
\text { yang terlalu banyak } \\
\text { sudah dihapus dan } \\
\text { diperbaiki. }\end{array}$ \\
\hline $\begin{array}{lrr} & \text { Peta konsep } \\
\text { diberi } & \text { keterangan } \\
\text { penghubung } & \\
\end{array}$ & $\begin{array}{lr} & \text { Peta konsep } \\
\text { telah diberi } & \text { kata } \\
\text { penghubung. } & \\
\end{array}$ \\
\hline $\begin{array}{lrr} & \text { Ada beberapa } \\
\text { tulisan } & \text { sumber } & \text { gambar } \\
\text { yang tidak } & \text { jelas/ } \\
\text { kontras, } & \text { seperti pada hal } \\
32 \text { dan } & \text { 45. Agar } & \text { dibuat } \\
\text { lebih } & \text { kontras } & \text { atau } \\
\text { tulisan } & & \text { sumber } \\
\text { diletakkan di } & \text { bawah } \\
\text { gambar. }\end{array}$ & \begin{tabular}{lr}
\multicolumn{2}{c}{ Semua } \\
gambar & hasil \\
pengambilan sudah \\
diberi sumber yang \\
kontras dan jelas.
\end{tabular} \\
\hline $\begin{array}{l}\text { Ketikan } \\
\text { kurang besar atau spasi } \\
\text { tulisan terdapat pada } \\
\text { halaman 41. Agar spasi } \\
\text { disamakan dengan } \\
\text { halaman lainnya. }\end{array}$ & $\begin{array}{r}\text { Tulisan } \\
\text { sudah disamakan. }\end{array}$ \\
\hline \begin{tabular}{lr}
\multicolumn{2}{c}{ Keterangan } \\
pada gambar & 2.11 tidak \\
selesai atau & komplit. \\
Agar & keterangan \\
tersebut & segera \\
dilengkapi. & \\
\end{tabular} & $\begin{array}{lc} & \text { Keterangan } \\
\text { pada } & \text { gambar } 2.11 \\
\text { telah } & \text { dilengkapi } \\
\text { keterangannya. }\end{array}$ \\
\hline $\begin{array}{l}\text { Secara } \\
\text { keseluruhan modul } \\
\text { Fisika sudah baik dan } \\
\text { menarik. }\end{array}$ & \\
\hline $\begin{array}{lc} & \text { Kesalahan } \\
\text { diksi, } & \text { penulisan } \\
\end{array}$ & $\begin{array}{l}\text { Tulisan } \\
\text { questioning, }\end{array}$ \\
\hline
\end{tabular}




\begin{tabular}{|c|c|}
\hline Sebelum & Setelah \\
\hline Revisi & Revisi \\
\hline $\begin{array}{l}\text { questioning, modelling, } \\
\text { dan inquiry tidak ditulis } \\
\text { secara miring. } \\
\text { Sebaiknya istilah asing } \\
\text { cari padanan kata } \\
\text { tersebut dalam bahasa } \\
\text { Indonesia. }\end{array}$ & $\begin{array}{lr}\text { modelling, } & \text { dan } \\
\text { inquiry telah ditulis } \\
\text { dengan aturan yang } \\
\text { benar dan telah dicari } \\
\text { kata lain dalam } \\
\text { bahasa Indonesia } \\
\text { yaitu bertanya, } \\
\text { pemodelan, r dan } \\
\text { menemukan. }\end{array}$ \\
\hline \begin{tabular}{l}
\multicolumn{3}{c}{ Kesalahan } \\
ejaan (preposisi) yaitu \\
pada penulisan di atas \\
dan di bawah yang \\
salah. \\
preposisi yang tidak \\
bermakna \\
penulisannya dipisah.
\end{tabular} & 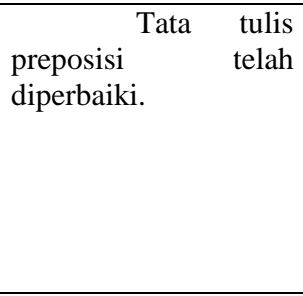 \\
\hline $\begin{array}{l}\text { Penulisan kata } \\
\text { ganti orang seperti anda } \\
\text { dan kalian yang salah } \\
\text { ejaannya (penulisan } \\
\text { huruf } \\
\text { Penulisan sapaan kata } \\
\text { ganti orang ditulis } \\
\text { dengan huruf kapital. }\end{array}$ & $\begin{array}{l}\text { Penulisan } \\
\text { kata ganti orang telah } \\
\text { diperbaiki dengan } \\
\text { awalan huruf kapital. }\end{array}$ \\
\hline $\begin{array}{l}\text { Secara } \\
\text { keseluruhan modul ini } \\
\text { disajikan secara runtut, } \\
\text { disajikan secara } \\
\text { menarik, dengan ulasan } \\
\text { materi singkat, pada dan } \\
\text { jelas. }\end{array}$ & \\
\hline \begin{tabular}{lrr} 
& \multicolumn{3}{c}{ Modul sangat } \\
layak di & uji & coba di \\
lapangan & & setelah \\
direvisi. & & \\
\end{tabular} & \\
\hline \begin{tabular}{l}
\multicolumn{2}{c}{ Tampilan } \\
modul sudah bagus, \\
warnanya menarik. \\
Hendaknya diperbaiki \\
bagian sampulnya. \\
\end{tabular} & $\begin{array}{l}\text { Sampul } \\
\text { telah diperbaiki. }\end{array}$ \\
\hline $\begin{array}{l}\text { Ada beberapa } \\
\text { kalimat yang salah. }\end{array}$ & $\begin{array}{r}\text { Kalimat } \\
\text { sudah diperbaiki. }\end{array}$ \\
\hline \begin{tabular}{l}
\multicolumn{2}{c}{ Tambahkan } \\
gambar pada mari \\
bertanya pada sub bab \\
asas Black.
\end{tabular} & $\begin{array}{l}\text { Sudah } \\
\text { ditambahkan gambar } \\
\text { aplikasi penerapan } \\
\text { asas Black dalam } \\
\text { kehidupan sehari-hari. }\end{array}$ \\
\hline $\begin{array}{l}\text { Ada beberapa } \\
\text { pengulangan keterangan } \\
\text { persamaan. }\end{array}$ & \begin{tabular}{l}
\multicolumn{2}{c}{ Pengulanga } \\
$\mathrm{n}$ keterangan yang \\
tidak perlu sudah \\
dihapus.
\end{tabular} \\
\hline $\begin{array}{l}\text { Tata } \\
\text { penulisan persamaan } \\
\text { diperbaiki lagi. }\end{array}$ & $\begin{array}{l}\text { Tata } \\
\text { penulisan persamaan } \\
\text { telah diperbaiki. }\end{array}$ \\
\hline \begin{tabular}{cc} 
& \multicolumn{2}{c}{ Penggunaan } \\
tanda baca dan
\end{tabular} & \begin{tabular}{l}
\multicolumn{2}{c}{ Semua } \\
tanda baca telah
\end{tabular} \\
\hline
\end{tabular}

\begin{tabular}{|c|c|}
\hline Sebelum & Setelah \\
\hline Revisi & Revisi \\
\hline $\begin{array}{l}\text { kesesuaian kalimat } \\
\text { diperbaiki kembali. }\end{array}$ & $\begin{array}{l}\text { disesuaikan dengan } \\
\text { kalimat tanya. }\end{array}$ \\
\hline $\begin{array}{llr} & \text { Ada beberapa } \\
\text { gambar } & \text { yang } & \text { kurang } \\
\text { jelas. } & & \\
\end{array}$ & \begin{tabular}{l}
\multicolumn{1}{c}{ Semua } \\
gambar yang kurang \\
jelas telah diganti.
\end{tabular} \\
\hline $\begin{aligned} & \text { Tata } \text { tulisan } \\
& \text { diperbaiki lagi. } \\
&\end{aligned}$ & $\begin{array}{l}\text { Tata tulisan } \\
\text { telah diperbaiki. }\end{array}$ \\
\hline $\begin{array}{l}\text { Gambar } \\
\text { kurang jelas harap } \\
\text { diperbaiki. }\end{array}$ & $\begin{array}{l}\text { Gambar } \\
\text { yang kurang jelas } \\
\text { telah diganti. }\end{array}$ \\
\hline
\end{tabular}

Berdasarkan Tabel 1. menunjukkan hasil validasi yang belum direvisi dan telah direvisi. Secara keseluruhan komentar dan saran adalah perbaikan dari segi penulisan dan gambar. Perbaikan penulisan mencakup tanda baca, penulisan nama dan penulisan persamaan yang tidak konsisten. Kemudian adanya pergantian peta konsep dengan menambahkan kata penghubung yang disarankan oleh validator materi. Setelah draft I direvisi dihasilkan modul draft II yang terbentuk karena adanya masukan dan saran dari validator. Kemudian draft II siap diujicobakan terbatas.

\section{Uji Coba Terbatas}

Tahapan uji coba terbatas ini dilakukan pada 9 orang siswa kelas XI IPA di SMAN 1 Sumberlawang. setelah mendapatkan produk yaitu modul cetak pembelajaran fisika berbasis kontekstual pada materi kalor dan perpindahannya yang sudah divalidasi oleh validator. Data hasil uji coba skala terbatas dikonversi ke dalam skala 4 dengan skor maksimal 92. Skor penilaian secara keseluruhan tersebut dikonversi ke dalam interval 4 maka diperoleh nilai penilaian 3,59 sehingga modul ini termasuk dalam kriteria 'sangat baik'. Nilai tersebut mengartikan bahwa menurut modul pembelajaran fisika berbasis kontekstual pada materi kalor dan perpindahannya yang dikembangkan sangat baik dalam segi isi/ materi, sangat baik dalam segi kebahasaannya dan sangat baik juga dalam segi gambar dan penyajiannya.

\section{Revisi II}

Hasil dari ujicoba terbatas juga berupa saran dan masukan dari siswa yang 
diperbaiki oleh peneliti, diantaranya perbaikan terhadap ketidakjelasan pertanyaan dalam kegiatan diskusi, tulisan pada sampul kurang jelas, contoh konsep yang kurang lengkap, hasil cetakan yang kurang jelas, dan terdapat beberapa penulisan yang kurang tepat. Setelah direvisi, hasil perbaikan kemudian disusun kembali menjadi draft modul III yang merupakan produk modul cetak yang siap digunakan untuk tahapan selanjutnya yaitu uji coba skala besar. Uji coba skala besar akan dilakukan pada siswa kelas X 1 SMAN 1 Sumberlawang yang berjumlah 32 siswa.

\section{Uji Coba Lapangan Utama}

Data yang didapatkan dalam uji coba lapangan dengan penerapan pembelajaran menggunakan modul pembelajaran fisika berbasis kontekstual pada materi kalor dan perpindahannya ini meliputi data hasil penilaian kemampuan sikap, pengetahuan, keterampilan, data kemampuan berpikir kritis dan data kreativitas belajar siswa. Selain hal tersebut, siswa juga diminta untuk melakukan penilaian terkait penggunaan modul.

\section{Penilaian Siswa Terhadap Modul}

Modul Fisika berbasis kontekstual ini setelah pembelajaran selesai dilakukan penilaian aspek materi, kebahasaan dan tampilan atau gambar dalam bentuk angket penilaian produk. Penilaian produk dilakukan pada 32 responden. Penilaian secara keseluruhan terhadap modul 3,57 yang masuk kategori sangat baik, hal ini mencakup aspek isi/materi bernilai 3,58, kebahasaan bernilai 3,59, tampilan/ gambar bernilai 3,57 yang mempunyai nilai masuk dalam kategori sangat baik. Hal ini menandakan bahwa modul Fisika berbasis kontekstual tersebut mempunyai kualitas sangat baik tersebut sangat baik digunakan sebagai salah satu alat pembelajaran sehingga dapat menjadi alternatif peningkatan hasil belajar. Hal ini seperti yang diungkapkan pada penelitian Jaya (2012).

\section{Penilaian Kreativitas Belajar Siswa}

Pada penilaian kreativitas ini dilakukan dengan pengisian angket sebelum dan setelah melakukan pembelajaran menggunakan modul Fisika berbasis kontekstual. Selain angket, penilaian kreativitas juga dilakukan melalui observasi. Setelah ini dilakukan pengambilan data menggunakan 26 butir angket yang valid dan reliable tersebut dikarenakan butir angket sudah memenuhi kriteria indikator kreativitas belajar siswa yaitu rasa ingin tahu, imajinatif, tertantang kemajemukan, berani mengambil resiko dan menghargai.

Hasil penilaian aspek kreativitas belajar yang terdiri dari rasa ingin tahu, imajinatif, tertantang kemajemukan, berani mengambil resiko, dan menghargai. Aspek rasa ingin tahu mengalami peningkatan sebesar $22 \%$, aspek imajinatif mengalami peningkatan $21 \%$, aspek tertantang kemajemukan mengalami peningkatan $17 \%$, aspek berani mengambil resiko mengalami peningkatan $14 \%$, dan yang terakhir adalah aspek menghargai mengalami peningkatan $17 \%$. Jika digambarkan melalui diagram batang dapat telihat jelas peningkatan kreativitas belajar siswa antara sebelum dan sesudah diberi modul Fisika berbasis kontekstual seperti pada gambar 2:

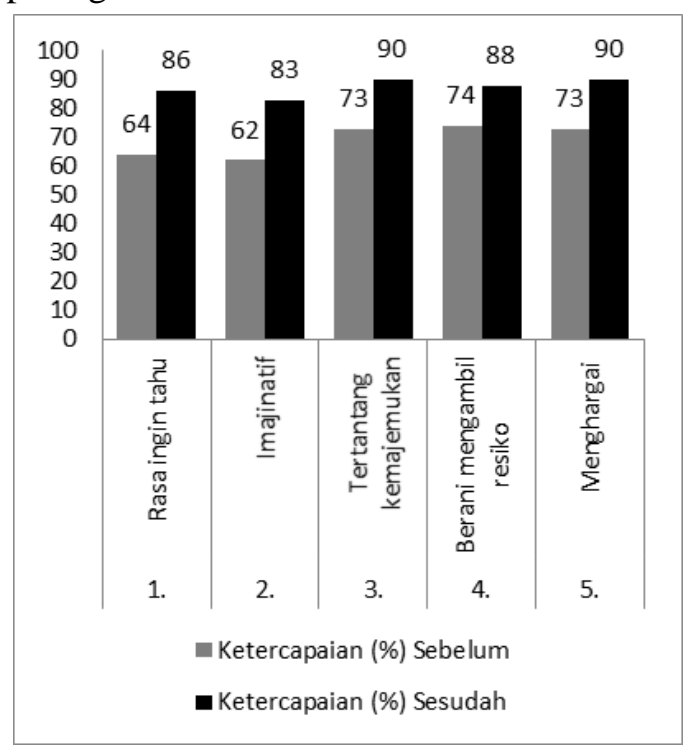


tanggung jawab, kreatif, jujur dan rasa ingin tahu.

Gambar 2. Hasil Perbandingan

\section{Persentase Ketercapaian Aspek Kreativitas Belajar Melalui Angket.}

Hasil skor rata-rata kreativitas belajar siswa tersebut menyimpulkan bahwa pembelajaran menggunakan modul Fisika berbasis kontekstual pada materi Kalor dan Perpindahannya dapat meningkatkan kreativitas siswa karena secara keseluruhan nilai gain 0,56 untuk angket dan 0,41 melalui observasi yang masuk kategori sedang. Modul Fisika berbasis kontekstual dikatakan dapat meningkatkan kreativitas belajar siswa jika nilai gain menunjukkan minimal kategori sedang $(0,41<\mathrm{n}$-gain < 0,60 ), hal ini sesuai dengan pernyataan Syaifudin (2011:43). Dengan adanya peningkatan kreativitas, dapat menumbuhkan kualitas belajar. Hal ini sesuai dengan pendapat Fasko (2001) yang berpendapat bahwa kualitas pembelajaran dapat ditingkatkan melalui peningkatan kreativitas dalam pembelajaran.

\section{Penilaian Hasil Belajar Aspek Sikap}

Penilaian aspek sikap pada penelitian ini mencakup rasa ingin tahu, tanggung jawab, jujur, kreatif, dan kerja keras. Penilaian sikap dilakukan dengan cara observasi yang dibantu oleh observer I dan observer II dalam penilaiannya dengan lembar observasi sikap. Hasil penilaian sikap menunjukkan bahwa secara keseluruhan siswa kelas X1 SMAN 1 Sumberlawang memiliki sikap dengan kategori sangat baik. Nilai secara keseluruhan dari sikap siswa adalah 3,35dalam skala 4 yang termasuk kategori sangat baik. Hal ini menunjukkan dengan pembelajaran Fisika dengan bantuan modul Fisika berbasis kontekstual memberi dampak positif terhadap penilaian sikap siswa dalam aspek rasa ingin tahu, jujur, tanggung jawab, kreatif dan kerja keras. Sikap yang paling terlihat dalam penilaian sikap adalah sikap kerja keras, kemudian

\section{Aspek Pengetahuan}

Penilaian aspek pengetahuan dilakukan pada saat proses pembelajaran dan juga pada saat akhir pembelajaran menggunakan modul Fisika berbasis kontekstual pada materi Kalor dan Perpindahannya. Penilaian asspek pengetahuan diambil dari soal evaluasi setiap kegiatan belajar (KB). Hasil penilaian menunjukkan nilai rata-rata keseluruhan siswa atau rata-rata kelas adalah 81, nilai tesebut melebihi nilai kriteria ketuntasan minimal (KKM) pelajaran Fisika yang bernilai 75. Hasil akhir menunjukkan bahwa $78 \%$ siswa lulus KKM dan 22\% siswa remidi, tetapi secara rata-rata kelas sudah lulus KKM. Hal ini sesuai dengan hasil penelitian Wasis (2006), yang menyatakan perangkat pembelajaran yang berbasis kontekstual yang telah dikembangkan dapat membantu siswa mencapai ketuntasan belajar. Selain itu, hal ini juga sejalan dengan hasil penelitian Jaya (2012) menyimpulkan bahwa produk berupa modul yang berbasis CTL dapat digunakan sebagai bahan ajar alternatif untuk meningkatkan hasil belajar Fisika.

\section{Aspek Keterampilan}

Penilaian aspek keterampilan atau aspek psikomotorik siswa di dalam penelitian ini berdasarkan lembar observasi aspek keterampilan. Penilaian dilakukan pada setiap kelompok saat kegiatan percobaan dalam salah satu kegiatan pembelajaran. Aspek penilaian yang dinilai pada aspek keterampilan siswa ini adalah persiapan percobaan, tahap percobaan, dan tahap pelaporan. Hasil penilaian aspek keterampilan menjelaskan bahwa secara keseluruhan siswa pada setiap kelompok memiliki nilai aspek keterampilan dengan kategori baik karena secara keseluruhan nilai keterampilan rata-rata kelas adalah 3,12 dalam skala 4. Aspek penilaian ratarata sudah baik, hal ini dijelaskan bahwa 
aspek persiapan percobaan mendapat nilai 3,17 dengan kategori baik, aspek tahap percobaan mendapat nilai 3,38 dengan kategori sangat baik, dan aspek tahap pelaporan mendapat nilai 2,83 dengan kategori baik.

\section{Penilaian Kemampuan Berpikir Kritis}

Kemampuan berpikir kritis dalam penelitian ini dilakukan tidak jauh berbeda dengan pengukuran kreativitas belajar siswa melalui pretest dan postest. Penilaian dilakukan dengan pretest dan postest sebelum dan sesudah pembelajaran menggunakan modul Fisika berbasis kontekstual materi Kalor dan Perpindahannya. Soal kemampuan berpikir kritis terdiri dari 22 item terpilih setelah dilakukan analisis butir soal dari 25 item. Pengambilan data menggunakan 22 item soal tersebut sudah mewakili selurus aspek kemampuan berpikir kritis yang dinilai dalam pembelajaran. Hasil penelitian menunjukkan Indikator interpretasi mengalami peningkatan $28 \%$, Indikator analisis mengalami peningkatan $9 \%$, inferensi mengalami peningkatan 13\%, evalusai mengalami peningkatan $13 \%$, penjelasan mengalami peningkatan $18 \%$. Kemudian yang terakhir indikator regulasi diri mengalami peningkatan 23\%. Secara keseluruhan semua indikator mengalami peningkatan $15 \%$. Hal ini sesuai dengan perhitungan nilai gain ternormalisasi yang menunjukkan nilai 0,50 yang termasuk kategori sedang. Sehingga dapat disimpulkan bahwa penggunaan modul Fisika berbasis kontekstual tersebut dapat meningkatkan kemampuan berpikit kritis siswa. Hal ini sesuai dengan pernyataan Syaifudin (2011:43) yaitu kemampuan berpikir kritis siswa dikatakan meningkat ketika hasil perhitungan nilai gain menunjukkan minimal kategori sedang. Peningkatan kemampuan berpikir kritis dapat digambarkan melalui diagram batang seperti pada Gambar 3 sebagai berikut:

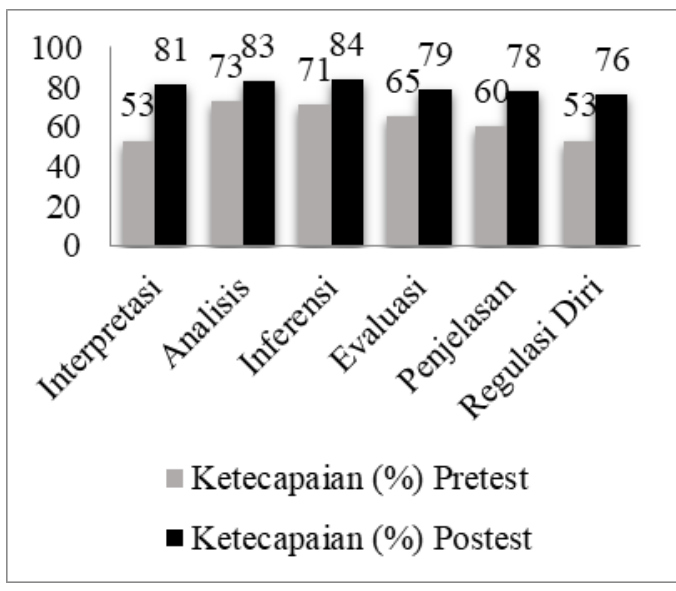

Gambar 3. Diagram Hasil Penilaian Kemampuan Berpikir Kritis

Berdasarkan Gambar 4 dapat disimpulkan bahwa dengan modul Fisika berbasis kontekstual dapat membuat siswa mempunyai kemampuan interpretasi, analisis, inferensi, evaluasi, penjelasan dan regulasi diri dengan baik. Hasil penelitian ini sesuai dengan hasil penelitian Wasis (2006) yang menyatakan perangkat pembelajaran yang menekankan pada kehidupan sehari-hari atau kontekstual dapat mengembangkn berbagai kecakapan, salah satunya adalah mengembangkan berfikir tingkat tinggi.

\section{Penyempurnaan (Revisi III)}

Berdasarkan hasil uji skala besar menunjukkan bahwa modul sudah sangat baik sehingga sudah layak ke tahap selanjutnya adalah tahap penyempurnaan modul. Tidak banyak hal yang dikukan dalam revisi penyempurnaan modul. Revisi hanya dilakukan pada perbaikan kata yang salah ketik. Selanjutnya modul yang telah direvisi pada tahap penyempurnaan siap untuk menuju tahap selanjutnya yaitu tahap penyebaran atau disseminate.

\section{Tahap Disseminate}

Pada tahapan penyebaran, modul Fisika berbasis kontekstual pada materi 
Kalor dan Perpindahannya untuk kelas X SMA/MA ini disebarkan di 3 sekolah di daerah Surakarta. Penyebaran dilakukan pada guru Fisika di SMAN 2 Surakarta sebagai responden 1, guru Fisika di SMA Batik 2 Surakarta sebagai responden 2, dan guru Fisika di SMA Al Abidin Surakarta sebagai responden 3. Setelah diberikan modul Fisika berbasis kontekstual pada materi Kalor dan Perpindahannnya, guruguru memberikan penilaian pada angket respon keterbacaan. medeskripsikan penilaian oleh guru terhadap modul Fisika berbasis kontekstual. Secara keseluruhan modul dinilai oleh ketiga responden tersebut masuk kategori sangat baik yaitu dengan rata-rata 3,7 dalam skala 4. Hal ini menunjukkan bahwa modul Fisika berbasis kontekstual yang sedang dikembangkan layak dipergunakan pada pembelajaran Fisika di SMA/ MA. Hal tersebut senada dengan hasil penelitian Sampurno (2009) bahwa pembuatan media pembelajaran yang baik sangat perlu dilakukan demi meningkatkan kualitas pembelajaran.

\section{Kesimpulan dan Rekomendasi}

\section{Kesimpulan}

Kesimpulan dari hasil penelitian pengembangan modul pembelajaran fisika berbasis kontekstual pada materi kalor dan perpindahannya untuk kelas X SMA/MA yang telah dilakukan adalah:

1. Karakteristik khusus pengembangan modul Fisika berbasis kontekstual pada materi Kalor dan Perpindahannya yang dikembangkan oleh peneliti dengan sintaks-sintaks pembelajaran kontekstual yang dituangkan pada rubrik dalam modul yaitu konstruktivisme (contructivism), bertanya (Questioning), menemukan (Inquiry), masyarakat belajar (Learning comunity), pemodelan (Modelling), refleksi (Reflection) dan penilaian sebenarnya (Authentic assesment).

2. Modul Fisika berbasis kontekstual pada materi Kalor dan Perpindahannya layak untuk digunakan sebagai bahan ajar.
Hal ini dapat dilihat dari hasil validasi ahli, ahli media, ahli bahas, guru Fisika dan teman sejawat dan hasil perhitungan cut off score menunjukkan modul masuk dalam kategori layak dengan nilai 3,62 dalam skala 4 dengan kategori sangat baik. Hasil perhitungan uji skala besar $94 \%$ siswa memberi penilaian kategori sangat baik dengan nilai 3,57 dalam skala 4 .

3. Pembelajaran dengan menggunakan modul Fisika berbasis kontekstual ini dapat meningkatkan kreativitas belajar siswa dan kemampuan berpikir kritis siswa dengan gain ternormalisasi diperoleh nilai 0,56 untuk kreativitas belajar siswa dan gain sebesar 0,50 untuk kemampuan berpikir kritis dengan kriteria gain ternormalisasi kategori sedang.

\section{Rekomendasi}

Dalam penggunaan modul pembelajaran berbasis kontekstual perlu diperhatikan beberapa hal diantaranya (1) Perlu adanya persiapan yang baik dalam pembelajaran menggunakan modul pembelajaran Fisika berbasis kontekstual proses pembelajaran dapat berlangsung dengan baik sesuai dengan RPP yang telah dipersiapkan. (2) Modul yang dikembangkan dapat dijadikan sebagai salah satu rujukan pengembangan bahan ajar oleh guru untuk meningkatkan kualitas pembelajaran. (3) Hasil penelitian ini dapat digunakan sebagai acuan untuk mengembangkan penelitian sejenis, terutama penelitian pengembangan modul dalam pembelajaran Fisika. Peneliti dapat mengembangkan modul dengan pendekatan pembelajaran dan materi yang berbeda.

\section{Daftar Pustaka}

Anita, Sri dkk. (2008). Strategi Pembelajaran di SD. Jakarta: Universitas Terbuka.

Asmani, J.M. (2011). 7 Tips Aplikasi PAKEM. Yogyakarta: Diva Press.

Depdiknas. (2007). Teknik Penyusunan Modul. Jakarta: Direktorat Jendral Manajemen 
Pendidikan Dasar dan Menengah, Departemen Pendidikan Nasional.

Fasko, D. (2001). Education and Creativity. Creativity Reasearch Journal 20002001, Vol. 13, Nos.3 \& 4. 317-327.

Goldin, G.A. (2002). Representation in Mathematical Learning and Problem Solving. Dalam L.D English (Ed). Handbook of International research in Mathematics Education (IRME). New Jersey: Lawrence Erlbaum Associates.

Harsono. (2009). Pengaruh Pembelajaran Kooperatif melalui Metode Problem Solving dan Pemberian Tugas Ditinjau dari Kreativitas Siswa. Tesis Tidak Dipublikasikan, Universitas Sebelas Maret, Surakarta.

Jaya, S. P. S. (2012). Pengembangan Modul Fisika Kontekstual untuk Meningkatkan Hasil Belajar Peserta Didik Kelas X Semester 2 di SMK Negeri3Singaraja.http://pasca.undiksha .ac.id/ejournal/index.php/jurnal_tp/arti cle.

Johnson, Elaine B. (2002). Contextual Teaching and Learning. California: Corwin Press Inc.

Lestari, Dian. (2014). Peranan Pendekatan Kontekstual Dalam Meningkatkan Komunikasi Matematis dan Kemandirian Siswa SMP. Prosiding Seminar Nasional Pendidikan Matematika Program Pasca Sarjana STKIP Siliwangi Bandung. Volume 1, pp 364-369. Diperoleh 20 September 2015 , dari http://publikasi.stkipsiliwangi.ac.id/file s/2014/01/Prosiding-15-Januari2014.pdf

Maharta,N, dkk. (2010). Pengaruh Remediasi Terhadap Miskonsepsi Fisika Siswa SMA Kelas X. FKIP Unila. Diakses 20 September 2015, dari http://jurnal.fkip.unila.ac.id/index.php/ JPF/article/viewFile/6105/3737

Meltzer, D.E. (2001). The Relationship between Mathematics Preparation and Conceptual Learning Gains in Physics: a Possible "Hidden Variable"in Diagnostic Pretest Scores.Department of Physics and Astronomy, Lowa State
University, Ames, Lowa 50011.Am. J. Phys. 70 (12).

Mundilarto. (2005). Pendekatan Kontekstual dalam Pembelajaran Sains. PPM Terpadu SMPN 2 Mlati. Yogyakarta: 20 April 2015.

Noperi, H. (2014). Pengembangan Modul Ilustratif Pembelajaran IPA SMP Berbasis Inkuiri Terbimbing Bermuatan Pendidikan Karakter. Thesis Tidak Dipublikasikan, Universitas Sebelas Maret, Surakarta

OECD. (2007). PISA 2006 science competencies for tomorrow's world. Volume 1. Paris, France: OECD.

Ornek, F., Robinson, W. R., Haugan, M. P. (2008). What Makes Physics Difficult?. International Journal of Environment and Sciences Education, 3 (1), 30-34. Turkey: Balikesir University. Diperoleh 20 September 2015, dari http://www.ijese.com/V3_N1_Ornek.p df.

Peraturan Pemerintah Nomor 19 tahun 2005 tentang Standar Nasional Pendidikan

Rianawaty, Ida. (2011). Sumber Belajar (Learning Resources). Diperoleh 2 Mei 2016, dari http://idarianawaty.blogspot.co.id/2011 /04/sumber-belajar-learningresources.html

Sampurno, A. (2009)Penerapan Metode Belajar Akif dalam Pembelajaran Berbasis Proyek untuk Meningkatkan Hasil Belajar. Yogyakarta : Universitas Negeri Yogyakarta.

Schleicher, Andreas. (2014). PISA 2012 Results inFocus: What 15-year-olds Know and What They Know. Paris: OECD

Sugiyanto. (2013). Pengembangan Modul Berbasis Inkuiri Terbimbing disertai Multimedia Pada Materi Keaneragaman Makluk Hidup di SMPN 1 Kendal Kabupaten Ngawi. Jurnal Bioedukasi. Volume 6 Nomor 1. Pp 22-33.

Suparno, Paul. (2009). Kajian Kurikulum Fisika SMA MA Berdasarkan kurikulum KTSP. Jakarta: PT Bumi Angkasa. 
Suryani, F. \&Fatkhulloh. (Ed.). (2012). Peningkatan Kreativitas Siswa dalam Proses Belajar Fisika pada Konsep Gelombang Elektromagnet Melalui Pembelajaran Think, Write, and Talk. Procending Pertemuan Ilmiah XXVI HFI Jateng \&DIY. Purworejo:-

Syahbana, A. (2012). Peningkatan Kemampuan Berpikir Kritis Matematis Siswa SMP Melalui Pendekatan Contextual Teaching and Learning. Edumatika. Volume 02, NO 01. April 2012. Diakses 20 September 2015, dari http://www.unja.ac.id/onlinejournal/onlinejournal/index.php/edumatica/article/vie wFile/604/538.

Syaifudin, A. (2011). Pengembangan Media Pembelajaran Berbasis Video Handphone Format 3gp Untuk Materi Pelajaran Fisika Kelas X Pokok Bahasan Perpindahan Kalor. Skripsi Tidak Dipublikasikan, Universitas Sebelas Maret, Surakarta

Thiagarajan, dkk. (1974). Instructional Development for Training Teacher of Exceptional children. Bloomington Indiana: Indiana University

Tze Kiong, T. et al. (2011). The Development And Evaluation of The Qualitis of Buzan Mid Mapping Module. Procedia - Social and Behavioral Sciences. Universiti Tun Hussein Onn Malaysia.

Wahyuningsih, A.N. (2011). Pengembangan Media Komik Bergambar Materi System Saraf Untuk Pembelajaran yang Menggunakan Strategi PQ4R: Jurnal PP. Volume 1, NO. 2. November 2015.

Wasis. (2016). Contextual Teaching And Learning (CTL) Dalam Pembelajaran Sains Fisika SMP. Cakrawala Pendidikan, Th XXV. Nol. Surabaya: FMIPA UNS.

Winnie, S. (2009). Pendekatan Kombinasi Metode AHP dan Metode Cut Off Point pada Tahap Analisis Keputusan Perancangan Sistem Informasi Penjualan PT.X.http://eprints.undip.ac.id. Diakses 10 Februari 201 